International Journal of Advancement in Life Sciences Research

\title{
Bioefficacy of New Species of Entomopathogenic Nematode, Steinernema dharanaii (Nematoda: Rhabditida: Steinernematidae) against Whitegrub, Holotrichia rustica (Coleoptera: Scarabaeidae)
}

\author{
Sanjay Paunikar ${ }^{* 1}$ and Nitin Kulkarni ${ }^{1,2}$ \\ *Northern Regional Centre, Zoological Survey of India, Deharadun-248 195, Uttarakhand, India \\ ${ }^{1}$ Forest Entomology Division, Tropical Forest Research Institute, P. O. RFRC,Jabalpur- 482021, Madhya \\ Pradesh, India \\ ${ }^{2}$. Director, Institute of Forest Productivity, (IFP) Gumla, Lalgutwa, Ranchi - 835303. Jharkhand, India. \\ ${ }^{*}$ Correspondence E-mail : sanjaypaunikar@gmail.com
}

\begin{abstract}
The bioefficacy study of new native species of entomopathogenic nematode, Steinernema dharanaii (TFRIEPN-15) against root grubs Holotrichia rustica infecting Tectona grandis crop of forest nurseries of central India was taken up under controlled laboratory conditions. The grub of $H$. rustica when exposed to range of Infective Juveniles (IJs) numbers dose dependant relationship by 10-15- and 2530-days old grubs. The younger grubs were more susceptible as compared to older ones. Minimum number of IJs, i.e. $300 \mathrm{Grub}^{-1}$ causes $13.33 \%$ mortality in younger 6 days after the exposure, followed by $46.66 \%$ at the IJs population of $600 \mathrm{IJs} \mathrm{Grub}^{-1}$ mortality in older grubs at population of $600 \mathrm{IJs}$ $\mathrm{Grub}^{-1}$ causes $26.66 \%$ mortality. IJs population of 900 to 3000 caused mortality ranging from 73.33 to $93.33 \%$ in younger grubs at par with each other $(P>0.05)$. IJ population of above $6000 \mathrm{IJs}$ caused $100.0 \%$ mortality in younger grub which was significantly superior $(P<0.05)$. The older grub also exhibited similar trends, however maximum of $93.33 \%$ mortality at the highest IJ population.

These experiments have proved that indigenous species of entomopathogenic nematodes can be used successfully control white grubs and other soil insect pests with eco-friendly and effective management techniques achieving cent-percent mortality of the target insect pests.
\end{abstract}

Keywords: Entomopathogenic nematodes, Biological control, Steinernema dharanaii, White grubs, Holotrichia rustica, Forest insect pests.

\section{Introduction}

White grubs (Coleoptera: Scarabaeidae) are also well known as 'The chafer beetles' and polyphagous root-feeding larvae of scarab beetles. They are notorious soil-borne insect pests of forestry, agricultural, horticultural, plantations crops, paster land and turf grass worldwide (Beeson, 1941, Browne, 1968; Jackson, 1992; Koppenhofer \& Fuzy 2008; Kulkarni, 2010; Rathee \& Dalal, 2018). White grubs have a wide distribution in India and found all the agro-climatic zones and becomes National Pest of India (Garg, et al., 2005; Mehta, et al., 2010, Bhawane, et al., 2012). Holotrichia species are one of the dominant species in India, causing damage to several crops of sugarcane, wheat, peanuts, groundnut, potato, soybean, and other economically important plants species 
(Yadava \& Sharma, 1995; Anitha, et al., 2006; Joshi \& Meshram, 2008; Thakare \& Zade, 2012; Lamani, et al, 2017). The active species of major concern different agricultural crops and forest nurseries are Holotrichia. serrata Fab., $H$. consanguinea Blanchard and $H$. reynaudi Blanchard (Syn: $H$. insularis Brenske) (Oka \& Vaishampayan, 1979; Thakur, 2000; Nair, 2007; Theurkar et al., 2013). Of late, they have also become major pests in teak forestry, particularly in production nurseries. These species cause heavy losses in teak seedlings in particularly in central India (Kulkarni et al., 2007, 2009; Kulkarni, 2010).

Kulkarni, et al. (2009) have reported the white grubs, Holotirchia rustica as notorious pest of teak (Tectona grandis L. f.) seedlings from India. There are only chemical pesticides management studies of whitergrub, Holotrichia rustica (Kulkarni, et al. 2009, 2012a).

The control of insect pests and non-insect pests are generally used by chemical pesticides and this is most popular method in India and abroad (Dhaliwal, et al., 2013). But that may lead to developing resistance by the target pest in addition to causing harms to human, wildlife, non-target biota and environment (Yadav \& Devi, 2017). Therefore, researchers have been studying to develop alternatives methods other than pesticides to control harmful insect pests in all over the world. Some effective alternative method to chemical pesticides is the microbial biocontrol agents with no harmful effects on human health, wild life and environment. The common microbial biocontrol agents are viruses, bacteria, fungi, and nematodes (Joshi \& Shukla, 2001; Vega \& Kaya, 2012; Kulkarni, 2014, 2017).

The Entomopathogenic Nematodes (EPNs) from the families Steinernematidae and Heterorhabditidae are among such alternatives as biological control agents against varied economically important insect pests, especially the ones inhabiting soil or in the cryptic habitats (Kaya, 1990; Hazir, et al., 2003; Grewal, et al., 2005; Bedding, 2006; Kulkarni, et al, 2008; Lacy \& Georgis, 2012; Paunikar, 2014, Sankaranarayanan \& Askary, 2017; Paunikar \& Kulkarni, 2019abc; Askary \& Mohmad, 2020).
Recent year, EPNs are gaining importance, because they possess many positive attributes of an effective biological control agent. EPN often have broad-spectrum effectiveness, short life cycles, amenability to mass production, recycling ability, persistence etc. and compatibility to several agrochemical products (Kaya and Gaugler, 1993; Kopenhofer and Grewal, 2005; Paunikar, et al., 2012, Kulkarni, et al., 2013; Shapiro-llan et al., 2014; Singh \& Upadhyay, 2018). EPNs have been tested successfully as potential biological control agents of many insect pests of forestry, agricultural, horticultural and plantation crops in India (Hussaini, et al., 2003; Divya \& Sankar, 2009; Paunikar, et al. 2010ab; Kulkarni, et al., 2011ab, 2017; Vashish, et al, 2018; Paunikar \& Kulkarni 2020ab).

The studied on the efficacy of different strain/species of entomopathogenic nematodes against many species of whitegrubs in India and abroad (Karunakaran 2000ab; Grewal et al., 2002; Ansari et al., 2003; Sharma et al., 2009; Khatri-Chhetri, et al., 2011; Gue, et al., 2014; Supekar \& Mohite, 2015; Patil \& Rangaswamy, 2018; Naik, et al., 2019).

This is first report on bioefficacy of entomopathogenic nematode, Steinernema dharanaii Kulkarni et al., 2012b (TFRIEPN-15) against Holotrichia rustica, important insect pest of forestry crops in India under laboratory conditions.

\section{Material and Methods}

The population of Steinernema dharanaii (TFRIEPN-15) was isolated under the environmental conditions of 28 to $36^{\circ} \mathrm{C}$ and relative humidity $40-78 \%$, as existing in nature during the monsoon season. The habitat of collection was soil of forest floor of dense teak (Tectona grandis L.) plantation. The soil sample collections were made from $10-15 \mathrm{~cm}$ depth, baited with the mature last instar larvae of (Bedding \& Akhurst, 1975). The recovered Infective Juveniles (IJs) of EPN were multiplied in laboratory in vivo on larvae of waxmoth, Galleria mellonella reared on modified artificial diet (Kulkarni et al., 2012c). The freshly emerged IJs of population of new 
species were used for experimental purpose for the present study.

\section{Collection of White grub}

The adult beetles of white grub species were collected from forest nurseries viz; Central Forest Nursery, Kundam Project Belkund, Forest Corporation of Madhya Pradesh, Ramdongari Forest Nursery, Nagpur and Chulband Forest Nursery, Gondia, Forest Development Corporation of Maharashtra in the month of June-July. Considering the nocturnal habit of the beetles collected from 8:00 PM to 11:00 PM. The adult beetles were brought and reared in the laboratory in 10 lit. Plastic containers/ buckets. The fresh leaves of the host plants were daily provided $\mathrm{ad}$ libitum. Eggs were separated daily and known aged grubs were used for the bioassay purpose.

\section{Laboratory Bioassay}

White grubs, 10-15 days (2nd instar grub) and 25-30 days (3rd instar grub) days were taken in Petridish (5 cm dia) with uniform quantity of soil filled in it. Only actively moving grubs were used in all bioassays experiments. Different doses viz; 300,600, 900, 1200, 1400, 3000 and $6000 \mathrm{IJs} \mathrm{grub}^{-1}$ of fresh IJs of TFRIEPN15 were released and the required moisture were given. After 24, 48, 72, 96, 120 hours observation were taken till the termination of the experiments. The dead grubs (cadavers) were kept in the separate Petri dish for emergence of IJs and counted the IJs production in each grubs. The experiment was repeated thrice before pooled data and compilation and statistical analysis.

\section{Statistical Analysis}

The insect mortality was corrected using Abbott's formula (Abbott, 1925). The data on mortality in infective juveniles were checked for skewness and symmetry and transformed using angular, square root or log base 10 transformations, as required. The transformed data (if required) were subjected to Analyses of Variance (ANOVA) (Gomez \& Gomez, 1984).

\section{Results and Discussion}

The grub of $H$. rustica when exposed to range of IJs numbers dose dependant relationship by 10-15- and 25-30-days old grubs. The younger grubs were more susceptible as compared to older ones. The minimum number of IJs, i.e. 300 Grub $^{-1}$ causes $13.33 \%$ mortality in younger grubs 6 days of after the exposure $(\mathrm{P}<00.5))\left(F_{(P<0.001)}=16.83, d f=26\right.$, $\left.S E_{(d) \pm}=11.01, L S D_{(P<0.005)}=22.56\right)$, followed by $46.66 \%$ at the IJs population of 600 IJs $\mathrm{Grub}^{-1}$ mortality in older grubs at population of 600 IJs Grub $^{-1} \quad 26.66 \%$ mortality. IJs population of 900 to 3000 caused mortality ranging from 73.33 to $93.33 \%$ in younger grubs at par with each other $(P>0.05)$. IJ population of above 6000 IJs caused $100.0 \%$ mortality in younger grub which was significantly superior $(\mathrm{P}<0.05) \quad\left(F_{(P<0.001)}=\right.$ 25.23, $d f=28, S E_{(d) \pm}=9.17, L S D_{(P<0.005)}=$ 18.78). The older grub also exhibited similar trends, however maximum of $93.33 \%$ mortality at the highest IJ population (Table 1; Fig. 1 \& 2).

Several species of whitegrubs are susceptible to entomopathogenic nematodes. There is no previous report available on these native EPNs against Holotrichia rustica, infesting forest tree species to compare obtained results. However, infectivity of EPNs against other scarabaeids reported by Rajeswari et al., 1984; Khusida, et al., 1987; Karunakaran, et al., 2000ab, Bhatnagar, et al., 2004 and Paschpur, et al., 2017.

Rajeswari, et al. (1984) studied the preliminary laboratory and field evaluation of DD-136 strain of $N$. carpocapsae against potato chafer grub, Anomala sp., conducted at Tamil Nadu Agricultural University, Coimbatore revealed that the nematode population ranging from 2000 to 6000 per grub in $220 \mathrm{~g}$ of soil and about 50,000 nematodes in irrigation water/meter row in potato field could bring about mortality of the grub under laboratory and field conditions respectively. Kushida, et al. (1987) investigated the pathogenicity of newly detected Steinernema sp. to scarabaeid larvae injurious to tree seedlings. These were highly infective to the larvae of all the species, causing high mortality at 4 or more days after inoculation. Inoculation with 100 nematodes was sufficient to cause high mortality of larvae 
of Anomala cuprea. Karunakaran et al. (2000a) observed that $S$. feltiae, S. glaseri were not infective to the eggs of white grub, $H$. serrata. S. glaseri caused significantly higher mean mortality of larvae of both $H$. serrata and $L$. lepidophora. Significantly less mortality of first instar grubs was caused by $S$. feltiae, while no mortality was observed in second and third instars. In another experiment, Karunakaran et al. (2000b) tested two EPN, S. glaseri and $H$. indica against different instars of white grubs, $H$. serrata and $L$. lepidophora. In laboratory conditions, Heterorhabditis took less time (3.80 days) than Steinernema (4.37) to cause mortality of $H$. serrata, while the trend was reversed in L. lepidophora.

Table 1:Bioefficacy of Steinernema dharanaii (TFRIEPN-15) against white grub, Holotrichia rustica.

\begin{tabular}{|c|c|c|}
\hline $\begin{array}{c}\text { Treatments } \\
\text { (Doses of IJs Grub-1) }\end{array}$ & $\begin{array}{c}\text { Mean Mortality in (\%) } \\
(\mathbf{1 0 - 1 5} \text { days Grubs) }\end{array}$ & $\begin{array}{c}\text { Mean Mortality in (\%) } \\
\text { (25-30 days Grubs) }\end{array}$ \\
\hline 300 & $13.33^{\mathrm{d}}$ & $0.00^{\mathrm{d}}$ \\
& $(13.82)$ & $(0.00)$ \\
\hline 600 & $46.66^{\mathrm{c}}$ & $26.66^{\mathrm{c}}$ \\
& $(39.91)$ & $(27.93)$ \\
\hline 900 & $73.33^{\mathrm{b}}$ & $63.33^{\mathrm{b}}$ \\
& $(65.26)$ & $(55.97)$ \\
\hline 1200 & $80.00^{\mathrm{b}}$ & $70.00^{\mathrm{b}}$ \\
& $(66.28)$ & $(60.15)$ \\
\hline 1500 & $80.00^{\mathrm{b}}$ & $70.00^{\mathrm{b}}$ \\
& $(66.28)$ & $(60.15)$ \\
\hline 3000 & $93.33^{\mathrm{b}}$ & $93.33^{\mathrm{a}}$ \\
& $(80.40)$ & $(80.40)$ \\
\hline 6000 & $100.00^{\mathrm{a}}$ & $93.33^{\mathrm{a}}$ \\
& $(90.04)$ & $(80.40)$ \\
\hline & $0.00^{\mathrm{d}}$ & $0.00^{\mathrm{d}}$ \\
\hline No Treatment $($ Control $)$ & $(00.00)$ & $(00.00)$ \\
\hline$F(p<0.001)$ & 16.83 & 25.23 \\
\hline$d f$ & 28 & 28 \\
\hline$\left.S E_{(\alpha) \pm}^{ \pm}\right)$ & 11.01 & 9.17 \\
\hline$L S D(p<0.005)$ & 22.56 & 18.78 \\
\hline
\end{tabular}

${ }^{*}$ Data in parenthesis are Arc Sin $\sqrt{n}$ transformation of percentage values.

$a, b$ Values followed by similar alphabets do not differ significantly with each other $(P>0.05)$.

Rajeswari, et al. (1984) studied the preliminary laboratory and field evaluation of DD-136 strain of $N$. carpocapsae against potato chafer grub, Anomala sp., conducted at Tamil Nadu Agricultural University, Coimbatore revealed that the nematode population ranging from 2000 to 6000 per grub in $220 \mathrm{~g}$ of soil and about 50,000 nematodes in irrigation water/meter row in potato field could bring about mortality of the grub under laboratory and field conditions respectively. Kushida, et al. (1987) investigated the pathogenicity of newly detected Steinernema sp. to scarabaeid larvae injurious to tree seedlings. These were highly infective to the larvae of all the species, causing high mortality at 4 or more days after inoculation. Inoculation with 100 nematodes was sufficient to cause high mortality of larvae of Anomala cuprea. Karunakaran et al. (2000a) observed that S. feltiae, S. glaseri were not infective to the eggs of white grub, $H$. serrata. S. glaseri caused significantly higher mean mortality of larvae of both $\mathrm{H}$. serrata and L. lepidophora. Significantly less mortality of first instar grubs was caused by $S$. feltiae, while no mortality was observed in second and third instars. In another experiment, Karunakaran et al. (2000b) tested two EPN, S. glaseri and $H$. indica against different instars of white grubs, $H$. serrata and $L$. lepidophora. In laboratory conditions, Heterorhabditis took less time (3.80 days) than Steinernema (4.37) 
to cause mortality of $H$. serrata, while the trend

was reversed in L. lepidophora.

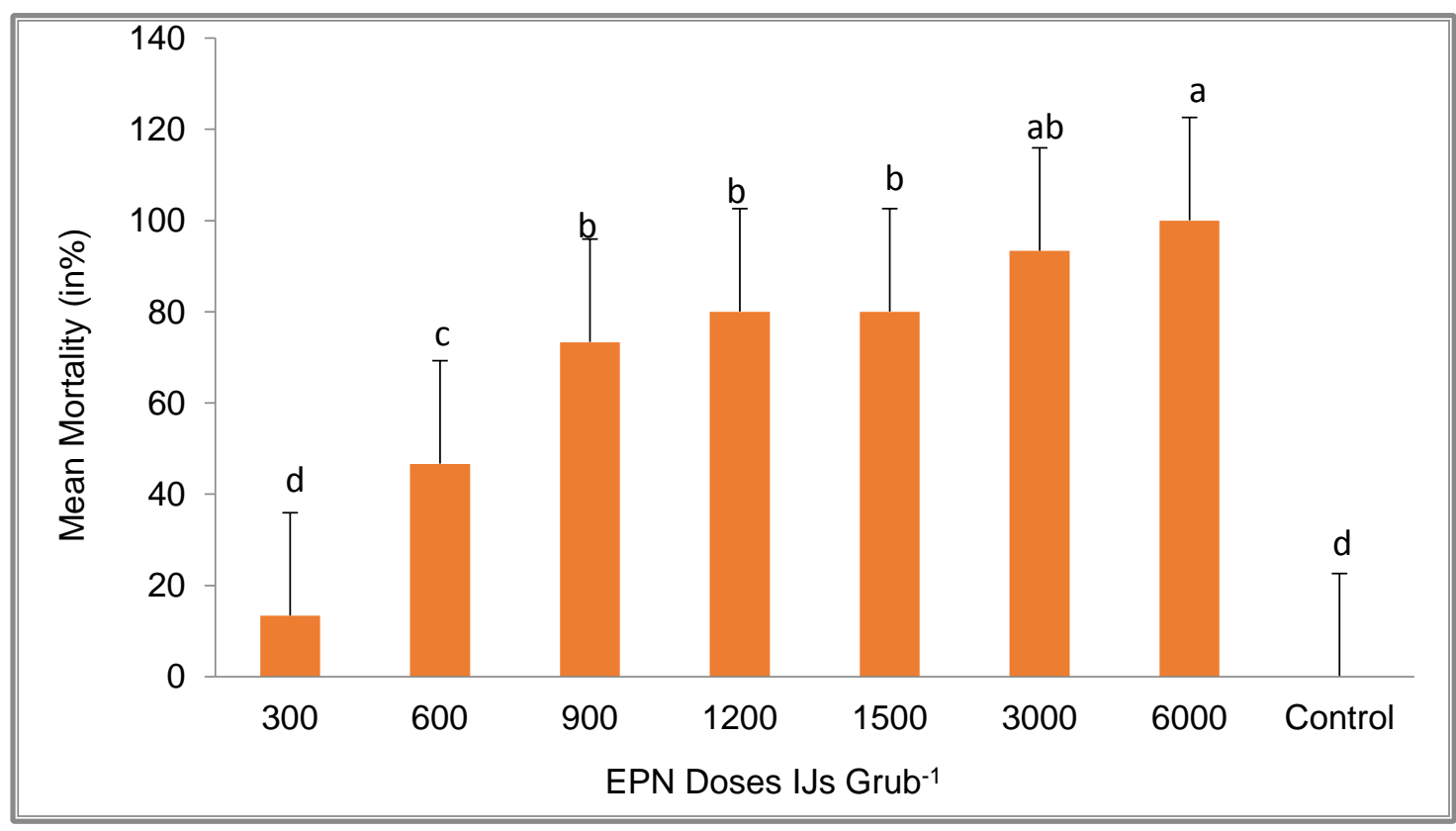

Fig. 1: Bioefficacy of TFRIEPN-15 against White grub, Holotrichia rustica (10-15 days)

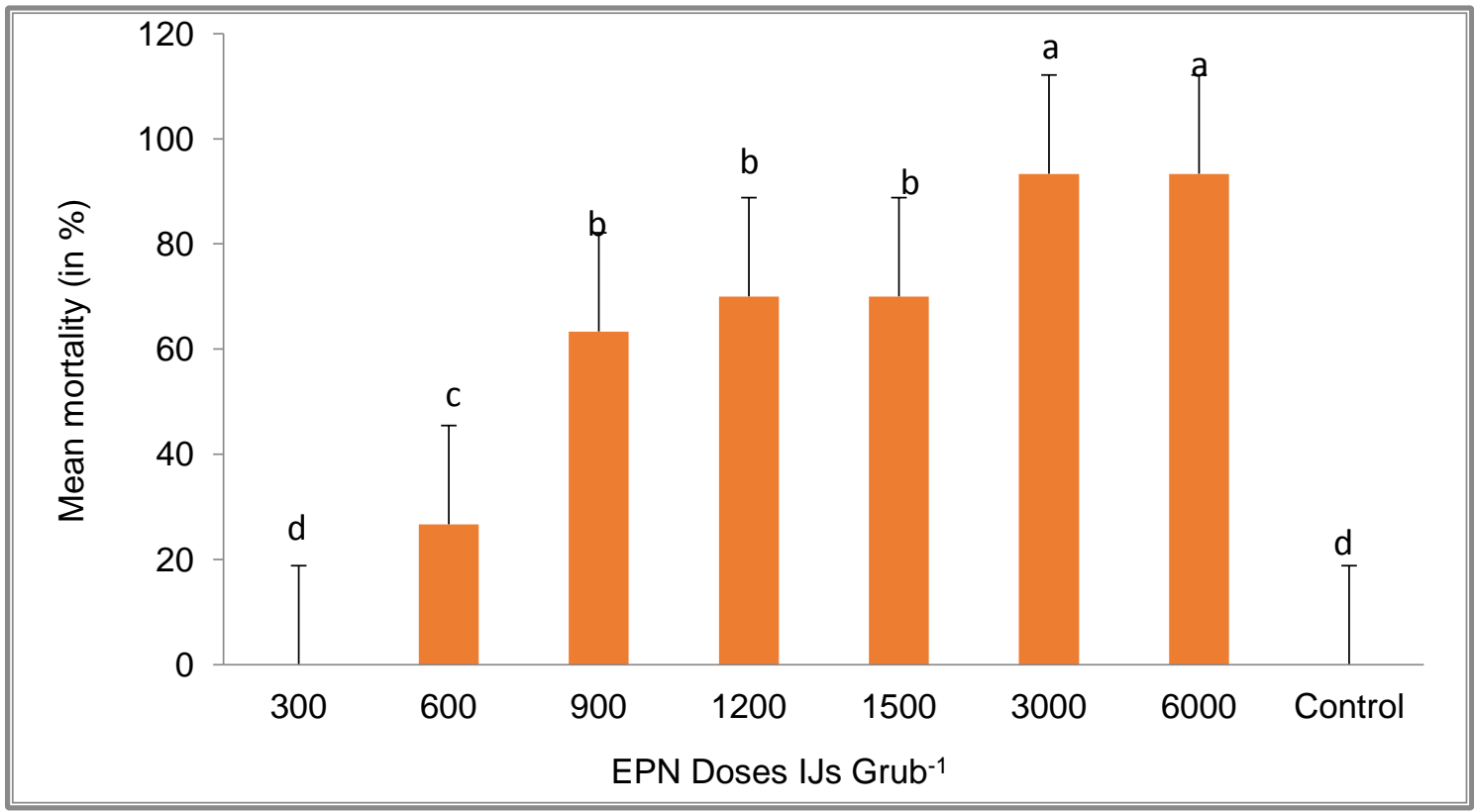

Fig. 2: Bioefficacy of TFRIEPN against white grub H. rustica (25-30 days)

Bhatnagar, et al. (2004) investigated white grubs or root grubs including Maladera insanabilis, are the phytophagous immature stages of scarabs, causing heavy economic losses to many field and plantation crops. Out of six entomopathogenic nematode species/strains: S. feltiae, Steinernema species, Ecomax strain, H. bacteriophora, $S$. glaseri, field collected (JFC) local isolate and Heterorhabditis species Ecomax strain, $H$. bacteriophora was found to be more virulent against the third instar grubs of $M$. insanabilis. Hussaini, et al. (2005) tested S. carpocapsae. $S$. bicornutum and $S$. glaseri (PDBC strain) against the white grubs of Holotrichia spp., in the laboratory by soil column assay. At a dosage rate of $750 \mathrm{IJs}^{\text {insect }}{ }^{-1}$ larvae. S glaseri larva infected successfully and multiplied in Holotrichia spp. Sanakaranarayan, et al. (2006) studied the effectiveness of four entomopathogenic nematodes (EPN) viz; $H$. indica (isolate LN2), 
H. bacteriophora, S. glaseri and S. riobrave against pupae and adult beetles of Holotrichia serrata a serious pests of sugar cane were evaluated in the laboratory. They found that all the species of EPNs caused mortality of the pupae.

Paschapur, et al. (2017) studied the bioefficacy of entomopathogenic nematode Heterorhabditis indica against third instar root grubs Holotrichia consanguinea infecting Sugarcane crop under controlled laboratory conditions. The results indicated that the mortality of grub was influenced by both the inoculum level and period of exposure. Time required for the mortality of the root grubs after inoculation with EPNs indicated that after 48 hours of treatment only $5.71 \%$ mortality was recorded and it reached up to $30.72 \%$ after 72 hours and significantly highest mortality $(56.43 \%)$ was observed after 96 hours of treatment.

Naik et al. (2019) investigated the native strains of entomopathogenic nematodes EPNs, S. carpocapsae and $H$. indica against arecanut white grub, Leucopholis lepidophora Blanchard. They found that EPN alone application of S. carpocapsae caused $74.3 \%$ and $79.1 \%$ and talc formulation of $\mathrm{H}$. indica caused $54.8 \%$ and $51.7 \%$ reduction in grub population in the respective.

Sharmila et al. (2019) tested two species of entomopathogenic nematodes against whitegrub Anomala communis in lab and pot culture. They showed that the highest larval mortality of 83.33 per cent and 19.04 per cent tuber damage was observed with S. glaseri @ $5 \times 109 \mathrm{lJ} / \mathrm{ha}$. At the same dosage, $H$. indica caused 71.66 per cent larval mortality and 38.09 per cent tuber damage.

\section{References}

Abbott, W.S. (1925). A method for computing the effectiveness of an insecticide. Journal of Economic Entomology, 18: 265-267.

Anitha, V., Rogers, D.J, Wightman. J. \& Ward, A. (2006). Distribution and abundance of whitegrubs (Coleoptera: Scarabaeidae) on groundnut in southern India. Crop Protection, 25:732-740.

Ansari, M.A.,Phan, K.L. \& Moens M. (2003)..Heterorhabditis bacteriophora (Heterorhabditidae: Rhabditida) parasitic in natural
Recently, Paunikar \& Kulkarni (2018, 2019abc, 2020ab) experimented of EPN, Steinernema dharanaii (TFRIEPN-15) against fictitious host insect wax moth, Galleria mellonella and some forest insect pests such as bamboo defoliator, Crypsiptya coclesalis, Albizzia defoliator, Sparima retorta, soil pests termites, Odontotermes obesus, teak defoliator, Hyblaea puera and teak skeletonizer, Eutectona machaeralis. They found that all these forest insect pests susceptible to new species of entomopathogenic nematode.

\section{Conclusion}

The results of the present study showed that whitegrub, Holotrichia rustica was suitable hosts for EPN, Steinernema dharanaii (TFRIEPN-15) isolated from Madhya Pradesh, Central India. It may be possible to use locally isolate native species of EPNs are more potential to control soil and cryptic habitat insect pests of the region. It is expected that the results of the study will provide useful information for future Integrated Pest Management (IPM) programs.

\section{Acknowledgments}

The author gratefully acknowledges to Tropical Forest Research Institute (ICFRE), Jabalpur, Madhya Pradesh for providing the technical support and laboratory facilities for conducting the experiments at Forest Entomology laboratory.

\section{Conflicts of Interest}

The authors declare that the research was conducted in the absence of any commercial or economic associations that could be construed as a potential conflict of interest

population of white grubs (Coleoptera: Scarabaeidae) in Belgium. Russian Journal of Nematology. 11: 57-59.

Askary, T.H. \& Ahmad, M.J. (2020). Efficacy of entomopathogenic nematodes against the cabbage butterfly (Pieris brassicae (L.) (Lepidoptera: Pieridae) infesting cabbage under field conditions. Egyptian Journal of Biological Pest Control. 30, 39. https://doi.org/10.1186/s41938-020-00243-y. 
Bedding. R. (2006).Entomopathogenic nematodes from discovery to application. Biopesticides International. 2: 87-119.

Bedding, R.A. \& Akhurst, R.J. (1975). A simple technique for the detection of insect parasitic rhabditid nematodes in soil. Nematologica, 21: 109116.

Beeson, C.F.C. (1941) The ecology and control of forest insects of India and neighboring countries. Vasant Press, Dehradun, India. p: 1007.

Bhatnagar, A. Shinde. V. \& Bareth, S.S. (2004). Evaluation of entomopathogenic nematodes against white grub, Maladera insanabilis Brenske International Journal of Pest Management, 50 (4): 285-289.

Bhawane, G.P., Mamlayya A.B., Wagh S.R. \& Chougule A.K. (2012). Diversity of white grub beetles and their host range from northern, western ghats, Kolhapur District (MS) India. The Bioscan, 7: 589-596.

Browne. F.G. (1968). Pests and diseases of forest plantation trees. Clerendon Press, Oxford, UK.

Dhaliwal, G.S., Singh, R. \& Jindal V.A. (2013). Textbook of Integrated Pest Management. Kalyani Publishers, New Delhi, India. pp: 448.

Divya, K. \& Sankar, M. (2009. Entomopathogenic nematodes in pest management. Indian Journal of Science and Technology. 2 (7): 53-60.

Garg, V.K., Kulkarni, N. \& Meshram, P.B. (2005). Influence of weather parameters on the incidenceof white grub, Holotrichia serrata Fabr. on teak seedlings in Chhindwara Forest Divisions. Indian Journal of Tropical Biodiversity, 13:48-51.

Gomez, K.A. \& Gomez, A.A. (1984). Statistical Procedures for Agricultural Research (2nd ed.), A Wiley-Interscience Publication, John Wiley \& Sons, New York. pp: 680.

Grewal, P.S., Koppenhofer, A.M. \& Choo H.Y. (2005). Lawn, turfgrass and pasture applications. In: Grewal PS, Ehlers R-U, Shapiro-llan DI (eds) Nematodes as biocontrol agents. CABI Publishing, Wallingford. Pp: 115-146.

Grewal, P.S., Grewal, S.K., Malik, V.S. \& Klein, M.G. (2002). Differences in susceptibility of introduced and native white grub species to entomopathogenic nematodes from various geographic localities. Biological Control, 24: 230237.

Guo, W., Yan, X., Zhao, G., Chen. J. \& Han, R. (2015). Efficacy of entomopathogenic Steinernema and Heterorhabditis nematodes against Holotrichia oblita. Journal of Pest Science. 88:359-368.
Hazir S, Kaya HK, Stock SP \& Keskün N (2003). Entomopathogenic nematodes (Steinernematidae and Heterorhabditidae) for biological control of soil pests. Turkish J Biology 27:181-202.

Hussaini SS, Rabindra RJ \& Nagesh M (2003). Current Status of Research on Entomopathogenic Nematodes in India. Project Directorate of Biological Control, PDBC, Bangalore, India. Pp:218.

Hussaini SS, Nagesh M, Dar M. and Rajeshwari R (2005). Field evaluation of entomopathogenic nemaotdes against white grubs (Coleoptera: Scarabaeidae) on turf grass in Srinagar. Journal of Plant Protection Sciences. 13(1): 190-193.

Jackson, T.A. (1992). Scarabs-pest of the past or the future. In T. A. Jackson and T. R. Glare (eds.), Use of pathogens in scarab pest management. Intercept Ltd., Andover, United Kingdom. Pp:1-10.

Joshi, K.C. \& Shukla, P.K. (2001). Recent Trends in Insect Pest Control to Enhance Forest Productivity, Proceedings of a Workshop on Entomology and Biological Control, Sept. 25th, Tropical Forest Research Institute, Jabalpur.

Joshi, K.C. \& Meshram, P.B. (2008). Whitegrub, Holotrichia threatening bamboo seedlings and its management. Indian Forester. 134:1257-1260.

Karunakar, G., Easwaramoorthy, S. \& David, H. (2000a). Host parasitic interactions between two species of whitegrubs infesting sugarcane and two species of EPNs. Sugar Technology. 2: 12-16.

Karunakaran, G., Easwaramoorthy, S. \& David, H. (2000b). Pathogenicity of steinenematida and heterorhabditid nematodes to white grubs infesting sugarcane in India. International Journal of Nematology. 10: 19-26.

Kaya, H.K. (1990). Soil ecology, in Entomopathogenic nematodes in biological control (Gaugler, R. and Kaya, H.K. eds.) CRC Press, Boca Raton, FL. Pp: 93-115.

Kaya, H.K. \& Gaugler, R. (1993) Entomopathogenic nematodes. Annual Review of Entomology. 38: 181-206.

Khatri-Chhetri, H.B., Timsina, G.P., Manandhar, H.K. \& Moens, M. (2011). Potential of Nepalese entomopathogenic nematodes as biocontrol agents against Holotrichia longipennis Blanch. (Coleoptera: Scarabaeidae). Journal of Pest Science. 84:457469.

Koppenhofer, A.M. \& Fuzy E.M. (2008). Early timing and new combinations to increase the efficacy of neonicotinoid-entomopathogenic nematode (Rhabditida: Heterorhabditidae) combinations 
against white grubs (Coleoptera: Scarabaeidae). Pest Management Science. 64:725-735.

Koppenhöfer, A.M. \& Grewal, P.S. (2005). Compatibility and interactions with agrochemicals and other biocontrol agents. In: Nematodes as Biocontrol Agents. CABI, New York, NY, pp:363381.

Kulkarni, N. (2010). Bioecology and management of white grub complex in teak forest nursery in India. In Cram, M. (Ed.) Proceedings of the 7th Meeting of IUFRO Working Party 7.03.04 Diseases and Insects in Forest Nurseries, Hilo, Hawaii, USA, July 13to 17, 2009.On-linepublication source: http:// www.fs.fed.us/r8/ foresthealth / publications/ nursery/l UFRO_7_03_04_HiloProc.pdf, Pp. 84-91.

Kulkarni N., Chandra, K., Wagh, P.N, Joshi, K.C. \& Singh, R.B. (2007). Incidence and management of white grub, Schizonycha ruficollis on seedlings of teak (Tectona grandis Linn. f.). Insect Science. 14, 411-418.

Kulkarni, N, Paunikar S, Joshi KC and Rogers J (2009) White grubs, Holotrichia rustica and Holotrichia mucida (Coleoptera: Scarabaeidae) as pests of teak (Tectona grandis L.f.) seedlings. Insect Science. 16:519-525.

Kulkarni, N., Paunikar, S. \& Singh, R.B. (2012a). Efficacy and field persistence of some insecticides against the white grub beetle, Holotrichia rustica (Burm.) (Scarabaeidae:Melolonthinae). Indian Journal of Entomology. 74(2): 105-107.

Kulkarni N. (2014). Status of potential of biocontrol component for integrated management of forest insect pests in India. In Biopesticides in Sustainable Agriculture: Progress and Potential, O. Koul, G.S. Dhaliwal, S. Khokar, and R. Singh, eds.), Science Publisher, New Delhi, India, 389-419.

Kulkarni N. (2017). Integrated insect pest management in tropical forestry. Rapisarda, $\mathrm{C}$ and Cocuzza, G.E.M. (eds.). Integrated pest management in tropical regions, CABI, UK. pp: 313342.

Kulkarni, N., Paunikar S., Hussaini. S.S. \& Joshi, K.C. (2008). Entomopathogenic Nematodes in insect pest management of forestry and plantations crops: An appraisal. Indian Journal Tropical Biodiversity. 16 (2): 156-165.

Kulkarni N., Paunikar, S., Mishra, V.K. \& Daksh, S. (2013). Tolerance of Entomophagenic nematode, Steinernema carpocapsae to some modern insecticides and biopesticides. Annals of Entomology. 31: 129-134.

Kulkarni N, Paunikar S. \& Mishra V (2011a). Pathogenicity of entomopathogenic nematode,
Heterorhabditis indica Poinar against the defoliator, Spirama retorta Cramer (Lepidoptera: Noctuidae) Insect Pest Management, A current Scenario, 2011. (Eds. Dunston P. Ambrose), Entomology Research Unit, St. Xavier's College Palayamkottai India. Pp312-115.

Kulkarni, N., Paunikar, S., Hussaini, S.S., \& Joshi K.C. (2011b). Susceptibility of teak skeletonizer, Eutectona machaeralis Walker to EPN, Heterorhabditis indica Poinar. World J Zoology. 6 (1):33-39.

Kulkarni, N., Mishra, V.K. \& Paunikar, S.D. (2017). Infectivity of native populations of entomopathogenic nematodes against teak defoliators. Journal of Entomology and Zoology Studies. 5 (6): 639-643.

Kulkarni N., Rizvi A, Vikas Kumar, Paunikar S \& Mishra V (2012b). Morphological and molecular characterization of Steinernema dharnaii sp. N. (Nematoda: Steinernematidae): An Entomopathogenic Nematode from India. Indian Journal of Tropical Biodiversity. 20 (2):107-116.

Kulkarni, N., Kushwaha DK, Mishra V.K. \& Paunikar, S. (2012c). Effect of economical modification in artificial diet of greater wax moth Galleria mellonella (Lepidoptera: Pyralidae). Indian Journal of Entomology. 74(4):369-374.

Kushida, T., Mamiya, Y. \& Mitsuhashi, J. (1987). Pathogenicity of newly detected Steinernema sp. (Nematoda) to scarabaeid larvae injurious to tree seedlings. Japanese. Journal of Applied Entomology and Zoology. 31: 144-149.

Lacey, L.A. \& Georgis, R. (2012). Entomopathogenic nematodes for control of insect pests above and below ground with comments on commercial production. Journal of Nematology.44(2):218-225.

Lamani, N., Guledagudda, S.S. \& Kambrekar, D.N.(2017). An economic impact of white grub infestation on sugarcane in Northern Karnataka. Journal of Entomology and Zoology Studies. 5(3): 18-23.

Mehta, P.K., Chandel, R.S. \& Mathur, Y.S. (2010). Status of whitegrubs in north western Himalaya. Journal of Insect Science. 23:1-14.

Naik, B.G., Maheshwarappa, H.P., Rajkumar M., Kalleshwaraswamy, C.M., Gowdra, N. \& Latha, S. (2019). Evaluation of entomopathogenic nematodes for the management of white grub, Leucopholis lepidophora Blanchard (Coleoptera: Scarabaeidae). Journal of Entomology and Zoology Studies. 7(1): 09-13. 
Nair, K.S. S (2007). Tropical Forest Insect Pests: Ecology, Impact and Management. Cambridge University Press, New York.

Oka, A.G. \& Vaishanpayan, S.M. (1979). White grubs menace in teak nurseries in Maharashtra. Second All India Symposium on Biology and Ecology. April, 1979. Bangalore, India.

Paschapur, A.U., Vijaya Lakshmi, K., Sunanda, B.S. \& Pawar, V. (2017). Virulence of Entomopathogenic Nematode (Heterorhabditis indica) against Sugarcane root grub (Holotrichia consanguinea). Bulletin Environment Pharmacology and Life Science. 6(1): pp 97-103.

Patil, J. \& Rangasamy, V. (2018). Field evaluation of the entomopathogenic nematodes against the white grub, Leucopholis lepidophora Blanchard (Coleoptera: Scarabaeidae). Egyptian Journal of Biological Pest Control.28:41.

Paunikar, S.D. (2014). Bioefficacy of entomopathogenic nematode native to Madhya Pradesh for the management of major forest insect pests. Ph.D. Thesis, Rani Durgawati University, Jabalpur Madhya Pradesh, India.

Paunikar, S. \& Kulkarni, N. (2019a). Evaluation of new species of entomopathogenic nematode, Steinernema dharanaii, (TFRIEPN-15) against Bamboo leaf roller, Crypsipyta coclesalis Walker (Lepidoptera: Pyralidae) in the laboratory. Indian Forester. 145(8):767-773.

Paunikar, S. \& Kulkarni, N. (2019b) Bioefficacy and Progeny Production of native new-to-science species of entomopathogenic nematodes, Steinernema dharanaii (TFRIEPN-15) against forest insect pest, Albizia defoliator, Spirama retorta Cramer (Lepidoptera: Noctuidae). Research Journal of Agriculture and Forestry Science. 7(4):10-16.

Paunikar, S. \& Kulkarni, N. (2019c). Efficacy of Entomopathogenic nematode, Steinernema dharanaii (TFRI-EPN-15) against termites, Odontotermes obesus (Isoptera-Termitidae) in the laboratory. Indian Journal of Forestry. 42 (4): 105108.

Paunikarm S., Mishra, V., Kulkarni, N. \& Hussaini, S.S. (2012). Tolerance of EPN, Heterorhbditis indica to some biopesticides. Pestology. XXXVI (3):41-44.

Paunikar, S., Mishra, V., Bhandari, R. \& Kulkarni N. (2010a). Entomopathogenic nematodes as biological control agents in insect pests management. Vaniki Sandesh. 1 (4): 11-17

Paunikar, S., Kulkarni, N., Mishra, V., Tiple, A., \& Hussaini, S.S. (2010b). Susceptibility of Teak Skeletonizer, Eutectona machaeralis Walker to
Steinernema carpocapsae, Hislopia Journal. 1 (2):165-170.

Paunikar, S., \& Kulkarni, N. (2020a). Compatibility of new species of entomopathogenic nematode, Steinernema dharanaii Kulkarni et al., 2012 (Nematoda: Rhabditida: Steinernematidae) from India with some modern biopesticides. International Journal of Environment, Agriculture and Biotechnology, 5(3) :99-105.

Paunikar, S. \& Kulkarni, N. (2020b). Pathogenicity and progeny production of new species of entomopathogenic nematode, Steinernema dharanaii Kulkarni et al., 2012 (Nematoda: Steinernematidae) against teak skeletonizer, Eutectona machaeralis Walker (Lepidoptera: Pyralidae) Walker under laboratory condition. International Journal of Zoology and Applied Biosciences. 5(3):170-170.

Paunikar, S. \& Kulkarni, N. (2018). of Entomopathogenic nematode, Steinernema dharanaii n.r. (TFRI-EPN-15) on greater wax moth, Galleria mellonella. Indian Journal of Entomology. 80 (4): 1506-1512.

Rajeswari, S., Menon, P.P. \& Sivagami, V. (1984). Preliminary tests with DD-136 for the control of potato chafer grub, Anomala sp. Indian Journal of Nematology. 14: 187-188.

Rathee, M. \& Dalal, P. (2018). Emerging Insect Pests in Indian Agriculture. Indian Journal of Entomology, 80(2): 267-281.DOI No.: 10.5958/0974-8172.2018.00043.3.

Sankaranarayanan, C. \& Askary, T.H. (2017). Status of entomopathogenic nematodes in integrated pest management strategies in India. (eds. M.M.M. Abd-Elgawad, T.H. Askary and J. Coupland). CAB International. pp :362-382.

Sankaranarayanan, C., Somasekar, N. \& Singaravelu B. (2006). Biocontrol Potential of Entomopathogenic Nematodes Heterorhabditis and Steinernema against Pupae and Adults of White grub Holotrichia serrata Fab. Sugar Technology.8 (4): 268-271.

Shapiro-Ilan, D.I., Han, R. \& Qiu X. (2014). Production of entomopathogenic nematodes. In Mass Production of Beneficial Organisms, Invertebrates and Entomopathogens (Ramos, J.M., Rojas, M.G., Shapiro-llan, D.I. eds.), Elsevier Inc., USA. Pp: 321-355.

Sharma, A., DeshRaj \& Chandla V.K. (2009). Use of Steinernema and Heterorhabditis nematodes for control of white grubs, Brahmina coriacea hope (Coleoptera: Scarabaeidae) in potato crop. Potato Journal. 36 (3-4): 160-165. 
Sharmila, R., Subramanian, S., Poornima, K. \& Anitha, K. (2019). Potential of Biocontrol Efficacy of Entomopathogenic Nematodes on White Grubs, Anomala communis (Coleoptera: Scarabaeidae) in Potato. International Journal of Research Studies in Zoology. 5(4): 8-15

Singh, A. \& Upadhyay, V. (2018). A Review on Entomopathogenic Nematodes: Heterorhabditis and Steinernema. Advances in Bioresearch. 9 (2): 214222.

Supekar, S. \& Mohite, P. (2015). Utilization of Entomopathogenic nematodes against white grub Holotrichia serrata Fab. infecting sugarcane. Journal of Global Biosciences, 4 (8):3178-3181.

Thakare, V.G. \& Zade V.S. (2012). Diversity of beetles (Insecta: Coleoptera) from the vicinity of Semadoh Makhala road, Sipnarange, Melghat Tiger Reserve, (MS) India. Bioscience Discovery. 3: 112115.

Thakur, M.L. (2.000). Forest Entomology. Sai Publishers, Dehradun. p: 609.

Theurkar, S.V., Patil, S.B., Ghadage, M.K., Zaware, Y.B. \& Madan, S.S. (2013). Distribution and abundance of White grubs (Coleoptera: Scarabaeidae) in Khed Taluka, part of Northern Western Ghats, MS, India. International Research Journal of Biological Science. 1(7): 58-60.
Vashisth, S., Chandel, Y.S, \& Chandel R.S. (2018). Biological control potential of North West Himalayan strains of Heterorhabditid nematodes against the turnip moth, Agrotis segetum (Denis \& Schiffermuller) (Lepidoptera: Noctuidae). Egyptian Journal of Biological Pest Control. 28:37.

Vega, F.E. \& Kaya, H.K. (2012). Preface. In:(Eds.). Insect Pathology, Seconded. Academic Press, SanDiego. p.xiii.

Yadav, C.P.S \& Sharma, G.K. (1995). Indian white grubs and their management. All India Coordinated Research Project on white grubs, Technical Bulletin No. 2, ICAR, New Delhi, India.

Yadav, I. C. \& Devi N.L. (2017). Pesticides Classification and Its Impact on Human and Environment. Environment Science and Engineering. 6: 141-157. 